| Peran Kepolisian

\title{
Peranan Kepolisian Dalam Penanggulangan Balapan Liar Menurut Undang-Undang Nomor 22 Tahun 2009 Tentang Lalu Lintas Dan Angkutan Jalan (Studi Kasus Di Polres Bone)
}

\author{
Dhya Wulandari \\ Institut Agama Islam Negeri (IAIN BONE) \\ Dhyaulandariiainbone@gmail.com
}

\begin{abstract}
Abstrak
Kajian dalam penelitian ini adalah peranan kepolisian dalam penanggulangan balapan liar menurut Undang-Undang Nomor 22 Tahun 2009 Tentang Lalu Lintas dan Angkutan Jalan (Studi Kasus di Polres Bone). Penelitian ini bertujuan untuk mengetahui bagaimana peranan dan penegakan hukum oleh kepolisian resort bone dalam penanggulangan balapan liar menurut Undang-Undang Nomor 22 Tahun 2009 Tentang Lalu Lintas dan Angkutan Jalan .Penelitian ini merupakan penelitian kualitatif. Pendekatan dalam penelitian ini adalah pendekatan normatifempiris. Jenis data dalam penelitian ini adalah Data Primer yakni data yang diperoleh langsung dari sumber data dari kepolisian Data Sekunder yakni data yang berfungsi sebagai pelengkap data primer. Metode pengumpulan data dalam penelitian ini adalah wawancara dan observasi. Tekhnik analisis data digunakan untuk menganalisis data, penulis menggunakan analisis kualitatif yaitu dimana data-data dikumpulkan dilakukan pemilihan selektif dengan disesuaikan pada permasalahan yang diangkat dalam penelitian ini. Hasil penelitian mengungkapkan bahwa Peran aparat Kepolisian Resort Bone bagian Satlantas sudah berperan aktif dengan melakukan upaya maksimal dalam penindakan kasus balapan liar seperti rutin melakukan Patroli diwaktu dan tempat yang marak terjadi balapan liar, namun juga diperlukan peran aktif masyarakat sekitar dan pemerintah daerah untuk menanggulangi aksi balapan liar, agar kasus balapan liar ini dapat diminimalisir secara maksimal apabila masyarakat dan pemerintah daerah sering melakukan koordinasi dengan pihak kepolisian dalam menanggulangi balapan liar.
\end{abstract}


Kata Kunci : Peranan Kepolisian, Penanggulangan Balapan Liar, dan UndangUndang Nomor 22 Tahun 2009 di Kabupaten Bone

\section{Pendahuluan}

Kegiatan balap motor ini biasanya dilakukan tanpa menggunakan standart keamanan dan keselamatan berkendara seperti tidak memasang body motor, lampu utama, lampu rem, lampu penunjuk arah, ban tidak ukuran standart, knalpot yang bersuara keras, tidak memakai helm dan jaket sebagai sarana keselamatan berkendara. Adib Bahari menyatakan bahwa sepeda motor harus lengkap, hal ini dikarenakan adanya aturan Pasal 285 ayat (1), bahwa setiap orang yang mengemudikan sepeda motor dijalan harus memenuhi persyaratan teknis dan layak jalan yang meliputi kaca spion, klakson, lampu utama, lampu rem, lampu penunjuk arah, alat pemantul cahaya, alat pengukur kecepatan, knalpot dan kedalaman alur ban. ${ }^{173}$ Tidak lengkapnya perlengkapan sepeda motor dapat menimbulkan rasa tidak nyaman dan gangguan ketertiban umum.

Dalam Undang-Undang Nomor 22 Tahun 2009 tentang Lalu Lintas dan Angkutan Jalan yang di dalamnya terdapat ketentuan larangan melakukan balapan liar yaitu Pasal 115 huruf b Undang-Undang Nomor 22 Tahun 2009 yang menegaskan "Pengemudi kendaraan bermotor di jalan dilarang berbalapan dengan kendaraan lain", dan pada Pasal 297 Undang-Undang Nomor 22 Tahun 2009 tentang Lalu Lintas dan Angkutan Jalan yang menegaskan "Setiap orang yang mengemudikan kendaraan bermotor berbalapan di jalan sebagaimana dimaksud dalam Pasal 115 huruf $\mathrm{b}$ di pidana dengan pidana kurungan paling lama 1 (satu) tahun atau denda paling banyak Rp.3.000.000,00 (tiga juta rupiah)", serta memenuhi unsur-unsur tindak pidana pada Pasal 503 ayat (1) Kitab Undang-Undang Hukum Pidana (KUHP). ${ }^{174}$ Tetapi realitasnya aksi balapan liar di bone semakin brutal seperti yang terjadi di ruas Jalan Jenderal Sudirman, Kelurahan Biru, Kecamatan Tanete Riattang, yang dimana aksi balapan liar digelar setiap malam Minggu dan membuat warga merasa sangat terganggu dengan aksi balapan liar tersebut.

173 Adib Bahari, 125 Tanya Jawab Aturan Wajib Berlalu Lintas, ( Yogyakarta: Pustaka Yustika,2010), h.85.

${ }^{174}$ Lihat Pasal 115 huruf b, Pasal 297, Pasal 503 ayat 1 Undang-Undang Nomor 22 Tahun 2009 tentang Lalu Lintas dan Angkutan Jalan.

Jurnal Al-Dustur; VOLUME 1 NO 1, DESEMBER 2018 
${ }^{175}$ Berdasarkan fenomena tersebut, maka penulis melakukan penelitian dengan judul "Peranan Kepolisian Dalam Penanggulangan Balapan Liar Menurut Undang-Undang Nomor 22 Tahun 2009 Tentang Lalu Lintas Dan Angkutan Jalan (Studi Kasus Di Polres Bone). “

\section{Rumusan Masalah}

Berdasarkan uraian dari latar belakang masalah di atas, maka rumusan masalah dalam penelitian ini adalah:

1. Bagaimana peranan kepolisian resort bone dalam penanggulangan balapan liar menurut Undang-Undang Nomor 22 Tahun 2009 tentang Lalu Lintas dan Angkutan Jalan?

2. Bagaimana penegakan hukum oleh kepolisian resort bone dalam penanggulangan balapan liar menurut Undang-Undang Nomor 22 Tahun 2009 tentang Lalu Lintas dan Angkutan Jalan?

\section{Defenisi Operasional}

Defenisi operasioal adalah variable yang dirumuskan berdasarkan karakteristik-karakteristik variable yang diamati. Defenisi operasional mempunyai arti tunggal dan diterima secara objektif, bilamana indikator variable yang bersangkutan tersebut tampak. ${ }^{176}$

Adapun defenisi operasional yang berkaitan dengan penelitian ini adalah sebagai berikut:

Peranan adalah yang diperbuat, tugas, hal yang besar pengaruhnya pada suatu peristiwa. ${ }^{177}$ Kepolisian adalah segala hal-ihwal yang berkaitan dengan fungsi dan lembaga polisi sesuai dengan peraturan perundang-undangan. ${ }^{178}$ Penanggulangan artinya, proses, cara, perbuatan mengatasi atau menyelesaikan. ${ }^{179}$ Balapan artinya, lomba adu kecepatan (mobil dan sebagainya). Liar artinya, tidak teratur, tidak

175 http://www.bonepos.com/aksi-balap-liar-di-bone-makin-brutal.html. Diunduh pada tanggal 03-10-2017.

${ }^{176}$ Saifuddin Azwar, Metode Penelitian (Yogyakarta; Pustaka Belajar, 2005), h. 74.

177 Kamus Lengkap Bahasa Indonesia,oleh D.Yanto,2008,h.481

178 Lihat Pasal 1 ayat 1 Undang-undang No.2 Tahun 2002 tentang Kepolisian Negara Republik Indonesia.

${ }^{179}$ http://kbbi.web.id/penanggulangan.html. Diunduh pada tanggal 15-09-2017 Jurnal Al-Dustur; VOLUME 1 NO 1, DESEMBER 2018 
menurut aturan (hukum). Jadi, Balapan liar artinya, kegiatan beradu cepat kendaraan, baik sepeda motor maupun mobil, yang dilakukan diatas lintasan umum. Artinya kegiatan ini sama sekali tidak digelar dilintasan balap resmi, melainkan di jalan raya. $^{180}$

Undang-Undang Nomor 22 Tahun 2009 tentang Lalu Lintas dan Angkutan Jalan adalah Undang-Undang yang terdiri dari beberapa pasal yang mengatur tentang lalu lintas dan angkutan jalan.

\section{Tujuan dan Kegunaan}

\section{1) Tujuan Penelitian}

Adapun yang menjadi tujuan penelitian ini adalah:

a. Untuk mengetahui peranan kepolisian resort bone dalam penanggulangan balapan liar menurut Undang-Undang Nomor 22 Tahun 2009 tentang Lalu lintas dan Angkutan Jalan.

b. Untuk mengetahui penegakan hukum oleh kepolisian resort bone dalam penanggulangan balapan liar menurut Undang-Undang Nomor 22 Tahun 2009 tentang Lalu Lintas dan Angkutan Jalan.

2) Kegunaan Penelitian

Kegunaan penelitian ini adalah sebagai berikut:

a. Kegunaan ilmiah yaitu untuk memberikan pengetahuan dan menambah wawasan mengenai peranan kepolisian resort bone dalam penanggulangan balapan liar.

b. Kegunaan praktis yaitu hasil penelitian ini diharapkan dapat menjadi pedoman bagi para pihak yang berkepentingan dalam menghadapi permasalahan balapan liar dapat membawa manfaat bagi penegak hukum khususnya pihak polisi lalu lintas di polres bone.

\section{Tinjauan Pustaka}

Dalam penelitian ini, penulis membutuhkan sumber bacaan yang dapat dijadikan sebagai bahan rujukan. Sumber bacaan yang dimaksud adalah sumber bacaan yang berupa karya ilmiah yang telah ada sebelumnya yang memiliki korelasi

${ }^{180}$ Wikipedia Bahasa Indonesia, Ensiklopedia Bebas, Balapan Liar. Diunduh pada tanggal 15-09-2017. 
dan relevansi dengan masalah yang penulis angkat sehingga dapat memberikan gambaran tentang sasaran penelitian yang akan dipaparkan dalam penelitian ini diantaranya:

Dhanang Sigit Tri P, Persepsi Masyarakat Terhadap Balap Liar Di Kalangan Remaja, Fakultas Ilmu Sosial dan Ekonomi Universitas Negeri Yogyakarta tahun 2010. Skripsi ini membahas mengenai Persepsi masyarakat terhadap balap liar di kalangan remaja. ${ }^{181}$

Putri Nurdiana, Penegakan Hukum Terhadap Tindak Pidana Perjudian Balap Liar Di Kawasan Radio Siaran Pemerintah Daerah (RSPD)Muntilan Magelang, Fakultas Syari'ah Dan Hukum Universitas Islam Negeri Sunan Kalijaga Yogyakarta tahun 2016. Skripsi ini membahas mengenai bagaimana penegakan hukum terhadap tindak pidana perjudian balapan liar. ${ }^{182}$

Perbedaan penelitian yang akan dilakukan oleh peneliti dengan penelitian terdahulu yang disebutkan di atas adalah dalam penelitian ini peneliti difokuskan pada peranan Kepolisian dalam Penanggulangan Balapan Liar menurut UndangUndang Nomor 22 Tahun 2009 Tentang Lalu Lintas dan Angkutan Jalan (Studi kasus di Polres Bone). Sedangkan penelitian di atas umumnya meneliti tentang bagaimana persepsi masyarakat terhadap balapan liar di kalangan remaja dan bagaimana penegakan hukum terhadap tindak pidana perjudian dalam balapan liar.

\section{Kerangka Pikir}

Berdasarkan Uraian di atas yang telah dikemukakan pada bagian terdahulu, maka pada bagian ini diuraikan kerangka pikir yang dijadikan sebagaian pedoman dan landasan berfikir dalam melaksanakan penelitian ini.

${ }^{181}$ Dhanang Sigit Tri P, http://eprints.uny.ac.id. Persepsi Masyarakat Terhadap Balap Liar Di Kalangan Remaja.pdf. Fakultas Ilmu Sosial dan Ekonomi Universitas Negeri Yogyakarta tahun 2010. Diunduh pada tanggal 15-09-2017.

182 Putri Nurdiana, http://digilib.uin-suka.ac.id. Penegakan Hukum Terhadap Tindak Pidana Perjudian Balap Liar Di Kawasan Radio Siaran Pemerintah Daerah (RSPD) Muntilan Magelang, Fakultas Syari'ah tahun 2016. Diunduh pada tanggal 15-09-2017. 
Adapun kerangka pikir yang dimaksud adalah sebagai berikut :

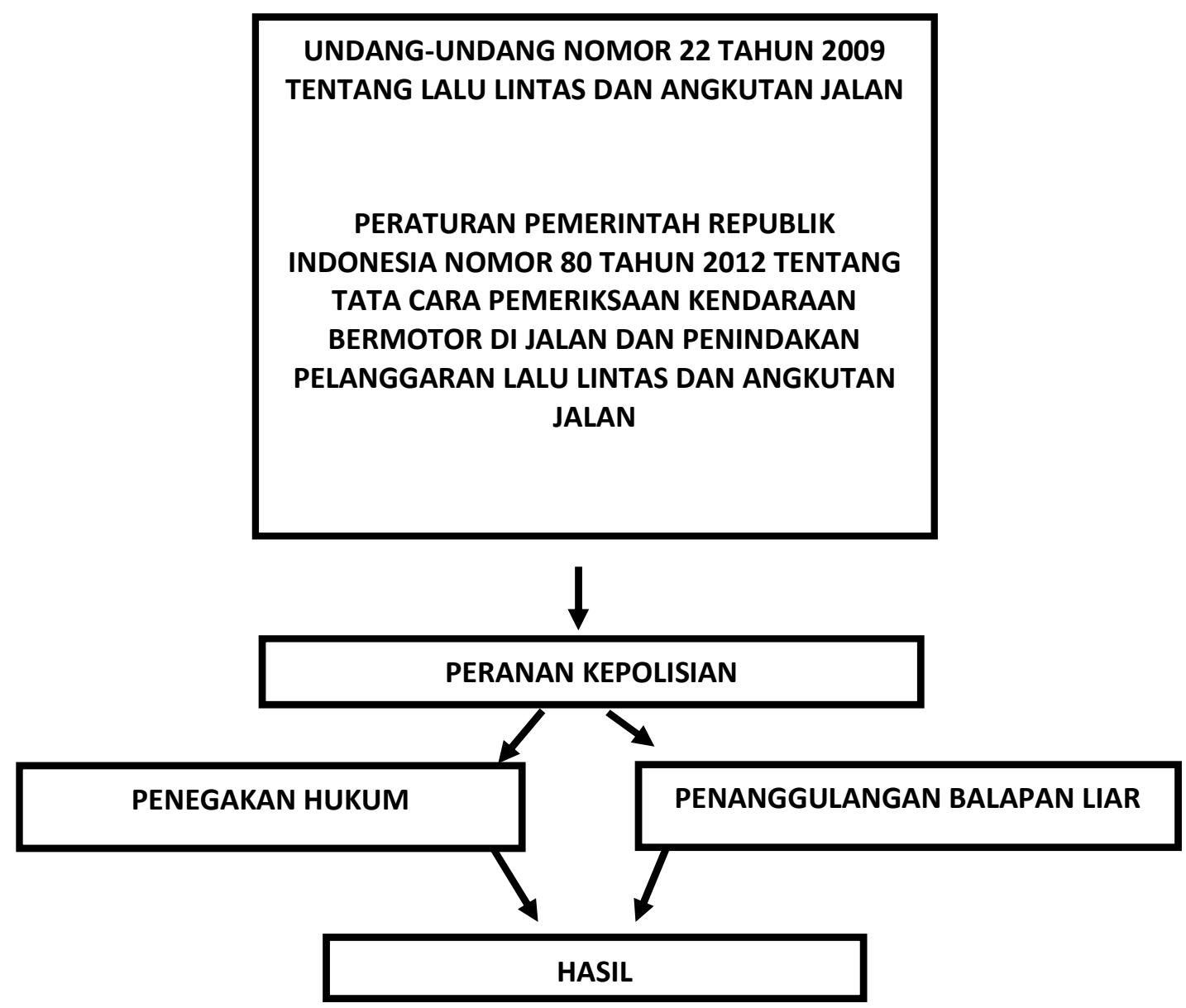

Bagan 1.1 Kerangka Pikir

Dari skema di atas dapat dipahami bahwa dalam penelitian yang dilakukan penulis adalah menganalisis aturan yang ada dalam Undang-Undang Nomor 22 Tahun 2009 tentang Lalu Lintas dan Angkutan Jalan, Peraturan Pemerintah Republik Indonesia Nomor 80 Tahun 2012 tentang Tata Cara Pemeriksaan Penindakan Pelanggaran Lalu Lintas dan Angkutan Jalan, Peraturan Pemerintah Republik Indonesia Nomor 37 Tahun 2017 tentang Keselamatan Lalu Lintas dan Angkutan Jalan dan tentang peranan dan penegakan hukum oleh kepolisian resort bone terhadap penanggulangan balapan liar. 
114 | Dhya Wulandari

\section{Metode Penelitian}

\section{Jenis dan Pendekatan Penelitian}

a. Jenis Penelitian

Adapun jenis penelitian yang akan dilakukan yaitu penelitian lapangan dengan metode kualitatif yaitu suatu metode yang digunakan dengan mendatangi langsung kantor Polres Bone dengan cara mewawancarai objek penelitian yang mana bertujuan untuk mempelajari secara intensif tentang latar belakang keadaan sekarang dan interaksi lingkungan suatu unit sosial (individu, kelompok, lembaga atau masyarakat). ${ }^{183}$

\section{b. Pendekatan Penelitian}

Pendekatan penelitian yang digunakan adalah pendekatan normatifempiris, yaitu mengulas dan menganalisis data berdasarkan fakta-fakta yang ditemukan di lapangan berdasarkan sudut pandang perundang-undangan dan ketentuan-ketentuan yang digariskan oleh peraturan pemerintahan. ${ }^{184}$

\section{Lokasi Penelitian}

Lokasi penelitian yang akan diobservasi oleh peneliti yakni dilakukan dalam wilayah hukum Polres Bone. Adapun alasan peneliti mengambil tempat di Kantor Polisi Resort (POLRES) Bone bagian Satuan Lalu Lintas (SATLANTAS), dikarenakan di Polres Bone merupakan instansi yang berwenang dalam penanggulangan balapan liar khususnya di bagian satuan lalu lintas.

3. Data dan Sumber Data

a. Data adalah catatan keterangan sesuai bukti dan kebenaran , bahan-bahan yang dipakai sebagai dukungan penelitian. ${ }^{185}$

b. Sumber Data adalah subyek dari mana data dapat diperoleh. ${ }^{186}$

Dalam penelitian ini akan diperoleh dua sumber data, yaitu:

${ }^{183}$ Abdullah K, Tahapan Dan Langkah-Langkah Penelitian (Cet. I; Watampone: Lukman Al Hakim Press, 2013), h. 27.

${ }^{184}$ Amiruddin dan Zainal Azikin, Pengantar Metode Penelitian (Jakarta:PT Raja Grafindo Persada,2004),h.166

${ }^{185}$ Kamus Lengkap Bahasa Indonesia,oleh D.Yanto,2008,h.148.

${ }^{186}$ Kamus Lengkap Bahasa Indonesia,oleh D.Yanto,2008,h.555. Jurnal Al-Dustur; VOLUME 1 NO 1, DESEMBER 2018 
1) Data primer, yaitu data yang diperoleh langsung dari sumber data dari kepolisian. ${ }^{187}$ Artinya data yang diperoleh secara langsung dari informan melalui observasi, wawancara dan studi dokumentasi. Adapun responden yang akan diwawancarai adalah polisi yang bertugas langsung dalam Satuan Lalu Lintas Polres Bone yang bergerak dalam pelaksanaan operasi kepolisian bidang lalu lintas dalam rangka penegakan hukum dan keamanan, keselamatan, ketertiban dan kelancaran lalu lintas. dan pelaku balapan liar.

2) Data sekunder, yaitu data yang bukan diusahakan sendiri pengumpulannya oleh peneliti, tetapi diperoleh dari biro statistik, majalah, keterangan-keterangan atau publikasi lainnya. ${ }^{188}$ Artinya data yang diperoleh dari literatur yang berkaitan dengan masalah yang dikaji dalam penelitian ini, misalnya buku-buku, penelitian, artikel, UndangUndang dan karya-karya ilmiah lainnya yang dipandang representatif. ${ }^{189}$

4. Teknik Pengumpulan Data

Adapun cara yang digunakan adalah sebagai berikut :

a. Observasi, Teknik ini menuntut adanya pengamatan dari si peneliti baik secara langsung ataupun tidak langsung terhadap obyek penelitiannya. Untuk memperoleh hal-hal yang biasanya tidak dapat diperoleh melalui wawancara maupun dokumentasi. ${ }^{190}$ Langkah-langkah dalam kegiatan observasi ini yaitu penulis mendatangi lokasi penelitian, mengadakan pencatatan, pengamatan langsung terhadap objek yang diteliti.

b. Wawancara yaitu (interview) situasi peran antar pribadi bertatap muka (face to face), ketika seseorang yakni pewawancara mengajukan pertanyaan-pertanyaan yang dirancang untuk memperoleh jawabanjawaban relevan dengan masalah peneliti kepada seorang informan. ${ }^{191}$

187 Abdullah K, Tahapan Dan Langkah-Langkah Penelitian hukum, (Cet.I,Watampone: Lukman Al Hakim Press, 2013), h. 41.

${ }^{188}$ Abdullah K, Tahapan Dan Langkah-Langkah Penelitian, (Cet. I; Watampone: Lukman Al Hakim Press, 2013), h. 42.

${ }^{189}$ Victorianus Aries Siswanto, Strategi dan Langkah-langkah Penelitian, Ed. Pertama (Cet. I; Yogyakarta: Graha Ilmu, 2012), h. 56.

${ }^{190}$ Husein Umar, Metode Penelitian untuk Skripsi dan tesis bisnis, (Cet.II;Raja Grsfindo Persada:Jakarta,1999), h. 51.

191 Amiruddin dan Zainal Azikin, Pengantar Metode Penelitian Hukum (Cet.II, Rajawali Pers:Jakarta,2004), h 82 
Biasanya dilakukan kepada sejumlah responden yang jumlahnya relatif terbatas dan memungkinkan bagi peneliti untuk mengadakan kontak langsung secara berulang-ulang sesuai dengan keperluan. ${ }^{192}$ Dan yang diwawancarai disini yaitu pihak kepolisian yang bertugas langsung dalam Satuan Lalu Lintas Polres Bone yang bergerak dalam pelaksanaan operasi kepolisian bidang lalu lintas dalam rangka penegakan hukum dan keamanan, keselamatan, ketertiban dan kelancaran lalu lintas. Dan pelaku balapan Liar.

c. Dokumentasi, Metode ini dipakai untuk mencatat data sekunder mengenai implementasi kebijakan tata tertib dan data yang bersifat dokumen lainnya. Langkah-langkahnya yaitu penulis mengumpulkan data dengan cara melihat, mencatat dan menggandakan dokumen secara tertulis yang ada kaitannya dengan objek yang diteliti.

5. Instrumen Penelitian

Instrumen penelitian adalah alat yang digunakan peneliti ketika melakukan proses pengumpulan data. Pemilihan Instrumen yang digunakan sangat tergantung pada jenis metode pengumpulan data yang digunakan seperti kamera, recorder dan alat tulis. Dalam penelitian kualitatif peneliti lebih banyak menjadi instrumen sebab dalam penelitian kualitatif peneliti merupakan kunci dari instrumen itu sendiri sehingga dalam penelitian ini yang menjadi instrumen penelitian selain alat-alat diatas juga peneliti itu yang berperan aktif.

6. Teknik Analisis Data

Teknik Analisis data dalam penelitian ini adalah analisis kualitatif, dimana data-data dikumpulkan dilakukan pemilihan selektif dengan disesuaikan pada permasalahan yang diangkat dalam penelitian ini

192 Sudarwan Danim, Menjadi Peneliti Kualitatif ( Cet. I; Bandung: CV. Pustaka Setia, 2002), h. 138. 


\section{Hasil Penelitian}

Sebagai Aparat penegak hukum yaitu khususnya pihak kepolisian berkewajiban untuk menjaga ketertiban umum agar tercipta keamanan dan kenyamanan dalam berlalu lintas dan memberikan rasa aman pada setiap pengendara kendaraan bermotor dengan berkomitmen menanggulangi aksi balapan liar yang dilakukan oleh para remaja menerapkan Undang-Undang Republik Indonesia Nomor 22 Tahun 2009 Tentang Lalu Lintas dan Angkutan Jalan agar dipatuhi oleh setiap masyarakat yang akan menggunakan jalan dan pengguna jalan umum. Iptu Fredy Nalle Kaur Bin Ops Satlantas Polres Bone menerangkan penegakan hukum yang dilakukan yaitu dengan upaya represif adalah suatu upaya penanggulangan aksi balapan liar secara konsepsional yang ditempuh setelah terjadinya Aksi Balapan Liar. Sanksi yang diberikan adalah menahan sesuai dengan Undang-Undang Nomor 22 Tahun 2009 dan diberikan hukuman sesuai dengan pasal 309, sanksi dendanya Rp.3.000.000,00, untuk adanya efek jera pihak kepolisian melakukan penahanan kendaraan selama 2 bulan. Penanggulangan dengan upaya represif dimaksudkan untuk menindak para pelaku kejahatan sesuai dengan perbuatannya serta memperbaikinya kembali agar mereka sadar bahwa perbuatan yang dilakukannya merupakan perbuatan yang melanggar hukum dan merugikan masyarakat, sehingga tidak akan mengulanginya dan orang lain juga tidak akan melakukannya mengingat sanksi yang akan ditanggungnya sangat berat ${ }^{193}$

${ }^{193}$ Iptu Fredy Nalle,Kaur Bin Ops Satlantas Polres Bone,Wawancara Penulis Di Polres Bone, 21 Februari 2018 
Daftar nama pelaku aksi balapan liar di Kabupaten Bone dari Tahun 2016 sampai 2018: ${ }^{194}$

\begin{tabular}{|c|c|c|c|}
\hline No. & Nama Pelaku Balapan Liar & Pekerjaan & Umur \\
\hline \multicolumn{4}{|c|}{2016} \\
\hline 1. & Nasrul & Pelajar & 17 \\
\hline 2. & Muhammad Riswansyah & Swasta & 23 \\
\hline 3. & Rian & Pelajar & 18 \\
\hline \multicolumn{4}{|c|}{2017} \\
\hline 1. & Indra Anugrah & Pelajar & 17 \\
\hline 2. & Andi Syarwan Almadani & Pelajar & 15 \\
\hline 3. & Rino & Pelajar & 16 \\
\hline 4. & Abdul Rahman & Pelajar & 16 \\
\hline 5. & Muhammad Yunus & Swasta & 46 \\
\hline \multicolumn{4}{|c|}{2018} \\
\hline 1. & Anto Bin Tahi & Pelajar & 16 \\
\hline 2. & Muhammad Amran & Swasta & 25 \\
\hline 3. & Andis & Pelajar & 16 \\
\hline 4. & Randi & Pelajar & 18 \\
\hline
\end{tabular}

Tabel 1.1 Daftar Nama Pelaku Aksi Balapan Liar di Kabupaten Bone

Berdasarkan tabel tersebut di atas jumlah pelaku aksi balapan liar selama 3 Tahun terakhir yaitu dari tahun 2016 sampai 2018 terdapat 12 kasus balapan liar. Pada tahun 2016 sampai 2017 mengalami peningkatan dan tahun 2017 sampai 2018 mengalami penurunan. Pada tahun 2016 terdapat 3 orang pelaku balapan liar, kemudian di tahun 2017 terdapat 5 orang pelaku balapan liar dan pada tahun 2018 terdapat 4 orang pelaku balapan liar. Adapun langkah-langkah pencegahan balapan liar dari pihak lalu lintas yang di terangkan oleh Iptu Fredy Nalle adalah dengan melakukan koordinasi terhadap camat, RT, RW, warga setempat, melakukan patroli di malam hari sekitar pukul 24.00 WIB atau jam 12 malam sampai dengan pukul

${ }^{194}$ Nuraiam, PNS Di Polres, Wawancara Penulis Di Polres Bone, 22 Feberuari 2018 Jurnal Al-Dustur; VOLUME 1 NO 1, DESEMBER 2018 
04.00 WIB atau jam 4 dini hari dimana balapan liar tersebut dilakukan oleh para remaja. ${ }^{195}$

\section{Kesimpulan}

setelah penulis melakukan penelitian yang berupa penelitian lapangan (field research) dengan judul Peranan Kepolisian dalam Penanggulangan Balapan Liar Menurut Undang-Undang Nomor 22 Tahun 2009 Tentang Lalu Lintas dan Angkutan Jalan (Studi Kasus Di Polres Bone), dapat memberikan kesimpulan sebagai berikut:

1. Peran aparat kepolisian Resort Bone bagian Satlantas sudah berperan aktif dengan melakukan upaya maksimal dalam penindakan kasus balapan liar seperti rutin melakukan Patroli di waktu dan tempat yang marak terjadi balapan liar, namun juga diperlukan peran aktif masyarakat sekitar dan pemerintah daerah untuk menanggulangi aksi balapan liar, agar kasus balapan liar ini dapat diminimalisir secara maksimal apabila masyarakat sering melakukan koordinasi dengan pihak kepolisian dalam menanggulangi balapan liar.

2. Pelaksanaan penegak hukum yaitu khususnya pihak kepolisian berkewajiban untuk menjaga ketertiban umum agar tercipta keamanan dan kenyamanan dalam berlalu lintas. Dan memberikan rasa aman pada setiap pengendara kendaraan bermotor penegakan hukum yang dilakukan yaitu dengan upaya represif adalah suatu upaya penanggulangan aksi balapan liar secara konsepsional yang ditempuh setelah terjadinya Aksi Balapan Liar. Sanksi yang diberikan adalah menahan sesuai dengan Undang-Undang Nomor 22 Tahun 2009 dan diberikan hukuman sesuai dengan pasal 309, sanksi dendanya Rp.3.000.000,00 , untuk adanya efek jera pihak kepolisian melakukan penahanan kendaraan selama 2 bulan. Penanggulangan dengan upaya represif dimaksudkan untuk menindak para pelaku kejahatan sesuai dengan perbuatannya serta memperbaikinya kembali agar mereka sadar bahwa perbuatan yang dilakukannya merupakan perbuatan yang melanggar hukum dan merugikan masyarakat.

195 Iptu Fredy Nalle, Kaur Bin Ops Satlantas Polres Bone,Wawancara Penulis Di Polres Bone,21 Februari 2018 
120 | Dhya Wulandari

\section{Referensi}

Al-Mawardi, Al-Ahkam Ash-Shulthaniyyah, terj. Khalifurrahman Fath dan Fathurrahman, Ahkam Sulthaniyah: Sistem Pemerintahan Khilafah Islam. Cet. I; Jakarta: Qisthi Press, 2015.

AL,Wisnubroto. PraktekPeradilanPidana. Yogyakarta: Galaxy Puspa Mega, 2002.

Amiruddin dan Zainal Azikin, Pengantar Metode Penelitian Hukum. Cet. 2; Jakarta: Rajawali Pers, 2004 .

Aries, Siswanto, Victorianus. Strategi dan Langkah-langkah Penelitian, Ed. Pertama Cet. I; Yogyakarta: Graha Ilmu, 2012.

Azwar, Saifuddin. Metode Penelitian. Yogyakarta; Pustaka Belajar, 2005.

Bahari, Adib. 125 Tanya Jawab Aturan Wajib Berlalu Lintas. Yogyakarta: Pustaka Yustika, 2010.

Bryan A.Garner, Blacks Law Dictionary, Seventh Edition, West Group, St.Paul, Minn, 1999.

D.Yanto,Kamus lengkap Bahasa Indonesia. 2008.

Danim, Sudarwan. Menjadi Peneliti Kualitatif. Cet. I; Bandung: CV. Pustaka Setia, 2002.

Hutama ,Kida. http://bagiartikel24.blogspot.co.id/penjelasan-dan-pengertian-balapanliar.html. Diunduh pada tanggal 15-09-2017.

Http://mykingdo.blogspot.co.id/2014/11/profesi-polisi-dalam-perspektif-hukum.html, Diunduh pada tanggal 29-01-2018.

Http://www.bonepos.com/aksi-balap-liar-di-bone-makin-brutal.html. Diunduh pada tanggal 03-10-2017.

IS, Susanto. Statistik criminal sebagai konstruksi social. Yogyakarta: Gentha Publishing, 2011. 